\title{
STUDI TENTANG PENGELOLAAN KEUANGAN DAERAH PERSPEKTIF PERMENDAGRI NO. 13 TAHUN 2006 PADA PEMERINTAH PROVINSI KALIMANTAN TIMUR
}

\author{
Al Mukaddas \\ Sekolah Menengah Kejuruan Negeri 1 Samarinda \\ E-mail: perpusmsi-unmul@gmail
}

\begin{abstract}
This study was conducted to determine the authority on financial management of East Kalimantan, analyze the financial management, and identify the regional authority perspective of east Kalimantan as stated in the Regulation of Minister of Home Affairs No. 13 in 2006 as the embodiment of good governance. The data used in this study was in the form of qualitative data which was obtained from the government of East Kalimantan and processed by applying qualitative descriptive analysis method and investigated using explorative approach. The results showed that the process of regional budget preparation of East Kalimantan has fully reflected the aspirations of the local community, the implementation of financial management has been organized effectively and efficiently in accordance with the idea of the Supreme Audit Institution $(B P K)$ presented in the financial statements of East Kalimantan in 2012 which obtained the qualification criteria that meet the expectations. In addition, the province inspectorate board has executed their duty to control the financial management satisfactorily where the testing accountability was completely supported by sufficient evidence and the results of the annual review of financial statements performed by Local Government Agencies (SKPD).
\end{abstract}

Keywords: Good Governance, Financial Budget, Accountability, Financial Statements

\begin{abstract}
Abstrak
Penelitian ini bertujuan untuk mengetahui tentang kewenangan pengelolaan keuangan Provinsi Kalimantan Timur, Menganalisis tentang manajemen keuangan, otoritas regional Kalimantan timur perspektif provinsi oleh Permendagri No 13 tahun 2006 sebagai perwujudan good governance. Data yang digunakan data kualitatif dari provinsi kalimantan timur regional. Penelitian ini menggunakan analisis deskriptif kualitatif dengan eksploratif. Hasil penelitian ini menunjukkan bahwa proses persiapan anggaran daerah provinsi kalimantan timur telah sepenuhnya mencerminkan aspirasi rakyat pelaksanaan pengelolaan keuangan daerah telah efektif dan efisien sesuai dengan pendapat BPK oleh pernyataan fiancial provinsi kalimantan timur pada tahun 2012 yang mendapatkan kualifikasi tidak asli harapkan. Dan kendali manajemen keuangan dilaksanakan oleh inspektorat provinsi kalimantan timur dengan pengujian akuntabilitas telah didukung oleh bukti yang cukup dan hasil review tahun laporan keuangan yang dilakukan oleh SKPD.
\end{abstract}

Kata Kunci: Good Governance, Anggaran Keuangan, Akuntabilitas, Laporan Keuangan 
UU No. 32 Tahun 2004 menggantikan UU No. 22 Tahun 1999 tentang pemerintahan daerah, mendukung perlunya dilaksanakan otonomi daerah untuk mempercepat terwujudnya kesejahteraan masyarakat. Melalui otonomi daerah, daerah otonom diberikan wewenang untuk mengatur dan mengelola sumber daya yang dimilikinya menurut kehendaknya sendiri untuk meningkatkan kesejahteraan masyarakatnya sesuai dengan aspirasi masyarakat dan peraturan perundang-undangan yang berlaku. Dengan cara meningkatkan pelayanan, pemberdayaan, peran serta masyarakat, dan daya saing daerah.

Pertimbangan yang mendasari perlunya diselenggarakan otonomi daerah adalah perkembangan kondisi internal dan eksternal. Arti dari internal adalah kondisi dalam negeri yang mengindikasikan bahwa rakyat menghendaki keterbukaan dan kemandirian (desentralisasi). Sedangkan arti eksternal adalah kondisi luar negeri yang menunjukkan semakin maraknya globalisasi yang menuntut daya saing setiap negara, dalam hal ini termasuk pemerintah daerah. Daya saing pemerintah daerah dapat dicapai melalui peningkatan kemandirian daerah.

Hal yang mendasar dari UU No. 32 Tahun 2004 adalah komitmen untuk mendorong dan memberdayakan masyarakat, pengembangan prakarsa dan kreatifitas, peningkatan peran serta masyarakat, pengembangan peran dan fungsi Dewan Perwakilan Rakyat Daerah. Karena daerah diberi kewenangan dalam perencanaan, pelaksanaan, pengawasan, pengendalian dan evaluasi seluruh fungsi-fungsi pemerintah yang telah didesentralisasi dalam rangka percepatan pembangunan pertumbuhan ekonomi.

Salah satu syarat yang diperlukan dalam pelaksanaan kewenangan tersebut adalah terdefinisi dan tersedianya sumbersumber keuangan untuk membiayai pemerintah daerah sebagai pelaksana pembangunan. Sehingga diberlakukan pola UU No. 33 Tahun 2004 menggantikan UU No. 25 Tahun 1999 yang mengatur tentang perimbangan keuangan antara pemerintah pusat dan pemerintah daerah. Berkaitan dengan pengaturan, pembagian, dan pemanfaatn sumber daya yang berkeadilan.

Sistem pengelolaan keuangan daerah merupakan sub sistem dari pemerintahan daerah yang saling terkait erat karena diperlukan pendanaan yang kokoh untuk penyelenggaraan desentralisasi dengan mempertimbangkan potensi, kondisi, dan kebutuhan daerah. Pengelolaan keuangan daerah harus dilakukan secara tertib, taat pada peraturan perundang-undangan, efisien, efektif, transparan dan bertanggung jawab berdasarkan asas keadilan dan kepatuhan.

Pengelolaan keuangan mempunyai pengaruh yang begitu besar bagi penduduk di wilayahnya. Karena tujuan akhir dari dilaksanakannya adalah untuk meningkatkan kesejahteraan rakyat sebagai wujud dari pelaksanaan tugas pemerintah.

Dalam rangka mendukung terwujudnya good governance, pengelolaan keuangan Pemerintah Provinsi Kalimantan Timur dilakukan secara profesional, terbuka dan bertanggungjawab sesuai dengan perundang-undangan yang berlaku. Pengelolaan keuangan daerah meliputi seluruh kegiatan perencanaan, penguasaan, penggunaan, pengawasan dan pertanggungjawaban. Keuangan daerah harus dikelola secara tertib, taat perundang-undangan, efisien, ekonomis, efektif, transparan dan bertanggung jawab dengan memperhatikan rasa keadilan dan kepatutan. Dengan memperhatikan Peraturan Menteri Dalam Negeri 
No. 13 Tahun 2006 pengelolaan keuangan daerah dapat dibagi menjadi empat bagian: 1. Penyusunan dan Penetapan APBD yaitu Anggaran sebagai perencanaan dan perwujudan pengelolaan keuangan daerah merupakan alat akuntabilitas, manajemen, dan kebijakan ekonomi. Penyusunan dan penetapan APBD dimaksudkan sebagai pedoman tercapainya tujuan penyelenggaraan pemerintahaan. Sebagai instrumen kebijakan ekonomi, anggaran berfungsi untuk mewujudkan pertumbuhan dan stabilitas perekonomian serta pemerataan pendapatan dalam rangka pencapaian tujuan, 2. Pelaksanaan APBD yaitu merupakan tindak lanjut dari perencanaan APBD yang ditetapkan dengan keputusan kepala daerah. Realisasi pelaksanaan APBD selama semester pertama harus dilaporkan dan dibuat kembali untuk pelaksanaan semester selanjutnya. Perubahan dan penyesuaian dalam pelaksanaan APBD dapat dilakukan apabila terjadi hal-hal berikut: perkembangan yang tidak sesuai dengan asumsi kebijakan umum daerah, keadaan yang mengharuskan terjadinya pergeseran anggaran, serta keadaan yang menyebabkan saldo anggaran lebih tahun sebelumnya harus digunakan untuk pembiayaan anggaran berjalan, 3. Pengawasan APBD adalah Pengawasan atas pelaksanaan APBD diperlukan untuk menjamin agar pelaksanaan APBD sesuai dengan peraturan perundang-undangan yang berlaku. Selain itu, dalam rangka mewujudkan good governance dan Clean goverment, pengawasan juga diperlukan untuk mendukung pengelolaan keuangan daerah yang efektif dan efisien, transparan, akuntabel, serta bersih dan bebas dari praktik-praktik KKN. Pengawasan terhadap pengelolaan keuangan daerah tersebut dapat dilakukan melalui pengawasan melekat, pengawasan masya- rakat dan pengawasan fungsional, 4 . Pertanggunjawaban Pelaksanaan APBD adalah Pertanggungjawaban pelaksanaan APBD disampaikan dalam bentuk Laporan Keuangan yang sekurang-kurangnya meliputiLaporan Realisasi Anggaran (LRA), Laporan Perubahan Saldo Anggaran Lebih (Laporan Perubahan SAL), Neraca, Laporan Operasional (LO), Laporan Arus Kas (LAK), Laporan Perubahan Ekuitas (LPE), dan Catatan Atas Laporan Keuangan (CaLK). Laporan keuangan tersebut merupakan Rencana Pembangunan Jangka Menengah Pemerintah Provinsi Kalimantan Timur merupakan salah satu upaya konkrit pemerintah daerah dalam mewujudkan asas transparansi dan akuntabilitas pelaksanaan pengelolaan keuangan daerah. Laporan keuangan disusun dan disajikan tepat waktu dengan bentuk dan isi yang sesuai dengan bentuk dan isi standar akuntansi pemerintahan pemerintah sebagaimana diatur dalam Peraturan Pemerintah No. 71 Tahun 2010. Sebagai perwujudan akuntabilitas laporan maka laporan keuanga diaudit oleh lembaga independen (dalam hal ini adalah BPK) sebelum disampaikan kepada DPRD dan pihak yang memerlukan.

Jika ditelusuri secara rinci pengelolaan keuangan daerah akan bersumber pada saat pemerintah daerah menyusun Rancangan Anggaran Pendapatan Belanja Daerah (RAPBD) sampai dengan pertanggung jawaban kepala daerah pada badan legislatif. Dengan diterapkannya penyusunan anggaran berbasis kinerja berarti semua kegiatan yang direncanakan harus berdasarkan output bukan lagi input. Anggaran semacam ini menjadi panduan bagi pemerintah daerahuntuk mengelola keuangannya dengan menerapkan konsep value for mney yaitu ekonomis, efektif dan efisien. 
Satu hal yang memegang peranan penting dalam melakukan suatu penelitian adalah kajian hasil-hasil penelitian sebelumnya. Hasil penelitian tersebut dapat dijadikan sebagai dasar dan perbandingan dengan penelitian yang akan dilakukan. Penelitian yang dimaksud tentunya adalah penelitian yang relevan dengan penelitian yang akan dilakukan ini.

Syafrida Fitrie (2008), yang mengambil judul "Pengelolaan Keuangan Daerah Perspektif Permendagri No. 13 Tahun 2006 Pada Pemerintah Kota Binjai”. Diperoleh kesimpulan bahwa proses penyusunan Anggaran Pendapatan dan Belanja Daerah di Kota Binjai belum mencerminkan sepenuhnya aspirasi masyarakat daerah di mana arah dan kebijakan umum anggaran lebih didominasi oleh kepentingan elit lokal di atasnya. Selain itu belum optimalnya peranan panitia anggaran Dewan Perwakilan Rakyat Daerah Kota Binjai sebagai wakil rakyat di daerah.

Keuangan daerah menurut Permendagri No. 13 Tahun 2006 pada pasal 1 angka 8 disebutkan bahwa pengelolaan keuangan daerah adalah keseluruhan kegiatan yang meliputi perencanaan, pelaksanaan, penata usahaan, pelaporan, pertanggung jawaban, dan pengawasan keuangan daerah.

Berdasarkan definisi di atas yang dimaksud dengan hak adalah hak untuk memungut sumber-sumber penerimaan daerah misalnya pajak, retribusi untuk menambah kekayaan daerah. Sedangkan yang dimaksud dengan kewajiban adalah kewajiban untuk mengeluarkan uang atau membayar sejumlah uang tertentu sehubungan adanya tagihan kepada daerah dalam rangka pembiayaan rumah tangga daerah serta pelaksanaan tugas umum dan tugas pembangunan oleh daerah yang bersangkutan.
Adapun keuangan daerah yang berhasil adalah keuangan daerah yang mampu meningkatkan penerimaan daerah secara berkesinambungan seiring dengan perkembangan perekonomian tanpa memperburuk alokasifaktor-faktor produksi dan keadilan serta sejumlah biaya administrasi tertentu.

Permendagri No. 13 Tahun 2006 tentang Pedoman Pengelolaan Keuangan daerah menjelaskan bahwa pengelolaan keuangan daerah adalah keseluruhan kegiatan meliputi perencanaan, pelaksanaan, penatausahaan, pelaporan, pertanggung jawaban, dan pengawasan keuangan daerah.

Tuntutan masyarakat terhadap peningkatan pelayanan dan kesejahteraan yang semakin baik, menjadi tantangan bagi pemerintah daerah untuk bekerja secara lebih efisien dan efektif khususnya dalam memberikan layanan kepada masyarakat. Tuntutan tersebut tidak lepas dari peranan pemerintah sebagai pelayan dan pelaksana pembangunan.

Pengelolaan keuangan daerah dilakukan secara tertib, taat pada peraturan perundang-undangan, efisien, ekonomis, efektif, transparan, dan bertanggung jawab dengan memperhatikan asas keadilan, kepatutan dan manfaat untuk masyarakat. Pengelolaan ini didasarkan pada APBD yang dibuat setiap tahunnya oleh pemerintah daerah dan ditetapakan dengan peraturan daerah.

Karena otonomi daerah bertujuan untuk mencapai Good governance, yaitu pemerintah daerah yang transparan, economies, efficient, effective, responsive, dan accountable. Maka otonomi daerah mengacu pada konsep value of money yang berkaitan dengan pengukuran ekonomis, efisien, dan efektifitas. 
Dalam Permendagri No. 13 Tahun 2006 Pemerintah melakukan pembinaan dan pengawasan pengelolaan keuangan daerah kepada pemerintah daerah yang dikoordinasikan oleh Menteri Dalam Negeri yang meliputipemebrian pedoman, bimbingan, supervisi, konsultan, pendidikan dan pelatihan.

Menurut Peraturan Menteri Negara Pendayagunaan Aparatur Negara nomor PER/05/M.PAN/03/2008, kegiatan utama APIP meliputi audit, reviu, pemantauan, evaluasi, dan kegiatan pengawasan lainnya berupa sosialisasi, asistensi dan konsultansi, namun peraturan ini hanya mengatur mengenai Standar Audit APIP. Kegiatan audit yang dapat dilakukan oleh APIP pada dasarnya dapat dikelompokkan ke dalam tiga jenis audit berikut ini: pertama, audit atas laporan keuangan yang bertujuan untuk memberikan opini atas kewajaran penyajian laporan keuangan sesuai dengan prinsip akuntansi yang diterima umum; kedua, audit kinerja yang bertujuan untuk memberikan simpulan dan rekomendasi atas pengelolaan instansi pemerintah secara ekonomis, efisien dan efektif; dan ketiga, audit dengan tujuan tertentu yaitu audit yang bertujuan untuk memberikan simpulan atas suatu hal yang diaudit. Yang termasuk dalam kategori ini adalah audit investigatif, audit terhadap masalah yang menjadi fokus perhatian pimpinan organisasi dan audit yang bersifat khas.

Era transparansi dan globalisasi merupakan suatu fenomena bagi setiap entitas organisasi dalam mempertanggung jawabkan setiap pekerjaan yang dilakukan, baik pada lingkup organisasi privat maupun organisasi publik. Pemerintah daerah adalah suatu entitas pelaporan keuangan publik yang harus mempertanggungjawabkan tata kelola keuangan daerah kepada stakeholder sebagaimana diatur dalam UndangUndang Nomor 17 Tahun 2003 tentang Ke uangan Negara dan Undang-Undang Nomor 1 Tahun 2004 tentang Perbendaharaan Negara.

Laporan keuangan pemerintah daerah adalah suatu bentuk pertanggungjawaban pemerintah daerah kepada stakeholder yang didalamnya mencakup berbagai macam pekerjaan yang membutuhkan keuangan, termasuk komponen aset yang tercermin dalam neraca daerah di mana setiap tahun dibuatkan laporannya setelah pelaksanaan anggaran. Pembuatan laporan keuangan ini dilakukan setelah adanya laporan keuangan Satuan Kerja Perangkat Daerah (SKPD) dengan batasan waktu dua bulan setelah tahun anggaran berakhir. Laporan tersebut meliputi Laporan Arus Kas, laporan Realisasi Anggaran, Catatan atas laporan Keuangan, dan Neraca SKPD. Laporan tersebut dilakukan paling lambat tiga bulan setelah anggaran tahunan berakhir.

Laporan keuangan merupakan tindak lanjut paket undang-undang tentang keuangan negara. Hal ini menjadi suatu fenomena baru bagi pemerintah, khususnya pemerintah daerah dalam melakukan pengelolaan keuangan agar menjadi lebih baik, walaupun dalam waktu singkat masih banyak yang kurang yakin bahwa pengelolaan keuangan sesuai paket undangundang tersebut dapat dilaksanakan dengan baik. Hal ini dapat dibuktikan dengan adanya pemerintahan daerah yang belum mampu melakukan pelaporan keuangan sesuai dengan peraturan yang ada. Secara kuantitas, hal ini tercermin melalui jumlah pemerintah daerah yang mendapatkan opini atau pendapat terbaik, Wajar Tanpa Pengecualian dari BPK mengenai pelaksanaan 
laporan keuangan, dimana hasilnya sangatlah belum memenuhi harapan masyarakat. Agar semua pemerintah dapat memperoleh opini atau pendapat terbaik, opini-opini atau pendapat-pendapat tersebut harus meliputi Wajar Tanpa Pengecualian (WTP), Wajar Dengan Pengecualian (WDP), serta Advers dan Disclaimer.

Asumsi-asumsi pertanyaan tersebut tidak harus menyalahkan pihak-pihak yang berkepentingan dalam pengelolaan keuangan daerah, namun diperlukan adanya suatu pemahaman yang sama antara pengambil kebijakan, pelaksana pengelola keuangan daerah, maupun para auditor sehingga pemerintah daerah akan lebih leluasa dalam memperbaiki mekanisme pengelolaan keuangan agar setiap tahun ada perbaikan.

\section{Metode Penelitian}

Untuk menjawab rumusan masalah yang diajukan dan tujuan penelitian yang hendak dicapai, maka rancangan penelitian yang digunakan adalah pendekatan aplikasi pengukuran pengelolaan keuangan daerah. Melalui pendekatan ini dapat diketahui secara obyektif tingkat efektivitas pelaksanaan pengelolaan keuangan daeran Pemerintah Provinsi Kalimantan Timur yang dikelola oleh pemerintah daerah ditinjau dari kajian akademis mengenai pencapaian tujuan atau sasaran dan proses pengelolaan serta pertanggung jawaban keuangan daerah.

Oleh karena itu, dalam rangka pendalaman terhadap pengelolaan keuangan daerah dengan metode penelitian deskriptif kualitatif yaitu, proses pemecahan masalah yang diselidiki dengan menggambarkan objek penelitian secara jelas dan lebih mendetail (komprehensif) serta untuk menarik generalisasi yang menjelaskan variabel yang menyebabkan suatu gejala atau kenyataan sosial.

Variabel dalam penelitian ini menggunakan satu variabel atau variabel tunggal, yaitu pengelolaan keuangan daerah berdasarkan proses perencanaan, pelaksanaan/implementasi dan pertanggung jawaban pengelolaan keuangan daerah.

Perencanaan, yaitu suatu input yang digunakan berdasarkan aspirasi masyarakat yang dilakukan olehPemerintah Daerah dan DPRD, yang hasilnya kemudian dijabarkan dalam usulan kegiatan masing-masing satu unit kerja dengan memperhatikan Standard Analisis Biaya (SAB) sehingga setiap aktivitas kegiatan yang diusulkan mencerminkan dukungan terhadap pencapaian visi, misi tujuan dan sasaran serta hasil yang telah ditetapkan.

Pelaksanaan/implementasi, yaitu input yang telah direncanakan sebelumnya digunakan dalam APBD yang telah ditetapkan, kemudian dilaksanakan dan dicatat melalui sistem akuntansi untuk menghasilkan laporan pelaksanaan APBD, baik berupa laporan yang sifatnya triwulan maupun tahunan bahkan bulanan kalau mungkin sebagai laporan pertanggung jawaban kepala daerah.

Pengawasan, yaitu suatu upaya yang sistematik untuk menetapkan kinerja standar pada perencanaan untuk merancang sistemumpan balik informasi, untuk membandingkan kinerja aktual dengan standar yang telah ditentukan, untuk menetapkan apakah telah terjadi suatu penyimpangan, serta untuk mengambil tindakan perbaikan yang diperlukan untuk menjamin bahwa semua daya perusahaan atau pemerintahan telah digunakan seefektif dan seefisien mungkin guna mencapai tujuan perusahaan atau pemerintahan. 
Metode yang digunakan dalam penelitian ini adalah metode penelitian deskriptif kualitatif, maka dalam penelitian ini tidak dikenal adanya sampel penelitian, melainkan informan penelitian. Informan adalah orang yang memberikan informasi tentang situasi dan kondisi latar belakang penelitian (Lexy, 1998: 80). Untuk dapat memperoleh informasi yang lebih jelas mengenai masalah penelitian yang sedang dibahas, maka penelitian menentukan informan kunci (key informan). Atas dasar pertimbangan tersebut ditentukan informan penelitian, yaitu: "Para stakeholder yang ada di Pemerintah Provinsi Kalimantan Timur"

Metode pengumpulan data yang digunakan untuk mendapatkan informasi meliputi pada penelitian ini adalah melalui Studi literature/Kepustakaan yaitu metode ini digunakan dengan cara menelusuri dan mengumpulkan bahan pustaka baik berbentuk literature, dokumen, jurnal maupun karya ilmiah untuk memperoleh kelengkapan data guna mendukung tersusunnya penelitian yang sempurna. Data yang diperoleh tersebut data sekunder dan digunakan sebagai pendukung dalam analisa data. Metode pengumpulan data yang kedua adalah Wawancara, merupakan metode yang mendukung untuk mendapatkan informasi yang diperlukan berkaitan dengan objek penelitian dengan berhadapan langsung dengan informan untuk mendapatkan informasi penelitian.

Dalam penelitian ini data diperoleh melalui penelitian deskriptif kualitatif artinya teknik ini berusaha menyimpulkan data yang berhubungan dengan objek penelitian serta berusaha menjelaskan dan menggambarkan variabel penelitian secara mendalam dan komprehensif (mendetail) sesuai dengan tujuan penelitian yang sudah dirumuskan. Tetapi teknik ini tidak menggambarkan hubungan satu variabel dengan variabel lainnya serta tidak menghasilkan teori baru dalam melihat hubungan antara variabel tersebut. Atas dasar itu dapat diketahui tentang pengelolaan keuangan daerah. Kemudian berdasarkan analisis tersebut dapat disusun dan ditentukan rekomendasi kebijakan terhadap permasalahan yang ada.

\section{Hasil Penelitian dan Pembahasan}

Sehubungan dengan ditetapkannya Permendagri Tentang Pedoman Pengelolaan Keuangan Daerah, maka dalam rangka mewujudkan akuntabilitas dan transparansi di lingkungan pemerintah daerah dalam hal pengelolaan keuangan daerah dituntut untuk menyusun Perencanaan Pengelolaan Keuangan Daerah melalui RKA dan DPA. Dokumen tersebut disusun serta disampaikan dalam laporan pertanggung jawaban pengelolaan keuangan dengan cakupan yang lebih luas dan tetap waktu.

Permendagri No. 13 Tahun 2006 tentang Pengelolaan Keuangan Daerah, menjabarkan lebih rinci komponen laporan keuangan yang wajib disampaikan oleh setiap tingkatan Pengguna Anggaran, Pengelola Perbendaharaan serta Pemerintah Daerah. Selain itu, diatur pula hubungan kegiatan akuntansi mulai dari tingkat satuan kerja pelaksana sampai tersusunnya Laporan Keuangan Pemerintah Daerah dengan jadwal yang telah ditentukan.

Analisis dalam penelitian ini digunakan untuk mengetahui proses pengelolaan keuangan daerah Pemerintah Provinsi Kalimantan Timur dimulai dari penyusunan anggaran dengan cara mendeskripsikan atau menggambarkan keadaan yang nyata terjadi, diamati dengan bertitik tolak pada pemahaman konsepsi serta pandangan atas teori yang terkait. 
Untuk mengimplementasikan Permendagri No. 13 Tahun 2006 tersebut, khususnya yang terkait penyusunan Laporan Keuangan dan Penatausahaan Keuangan SKPD, yang mencakup beberapa aspek penting dalam Pengelolaan Keuangan Daerah.

Proses Penyusunan APBD yang di dalamnya menyususn laporan: 1) Penyusunan KUA dan PPAS; 2) Penyiapan pedoman penyusunan RKA SKPD, 3) Penyusunan RKA SKPD; 4) Penyiapan Raperda APBD; 5) Pembahasan Raperda APBD dan Penyusunan Raper KDH Penjabaran APBD; 6) Evaluasi Raperda APBD dan Raper KDH Penjabaran APBD; 7) Penetapan Perda APBD dan Per KDH Penjabaran APBD; 8) Pembatalan Perda APBD dan Per KDH Penjabarab APBD; 9) Penyusunan Raper KDH APBD; 10) Penetapan Raper KDH APBD.

Pelaksanaan dan Penatausahaan Belanja, dimana didalamnya menyususn laporan tentang: 1) Penyiapan Rancangan DPA-SKPD dan Rancangan Anggaran Kas; 2) Penyusunan Rancangan DPASKPD; 3) Pengesahan Rancangan DPASKPD; 4) Penyediaan Dana; 5) Pembelanjaan Dana UP; 6) Pembelanjaan Dana GU; 7) Pembelanjaan Dana TU; 8) Pembelanjaan Dana Gaji; 9) Pembelanjaan Dana Barang \& Jasa; 10) Pembelanjaan Dana Barang \& Jasa - Non pihak Ketiga, 11) Pembelanjaan Dana Bunga, Subsidi, Hibah, Bantuan dan Pembiayaan; 12) Dana Cadangan; 13) Pembuatan SPJ; 14) SPJ dengan Bendahara Pembantu

Pelaksanaan dan Penatausahaan Pendapatan, yaitu menyusun laporan berkaitan: 1) Pelaksanaan Pendapatan DaerahBendahara Penerimaan; 2) Pelaksanaan Pendapatan Daerah-Bendahara Penerima- an Pembantu, 3) Pelaksanaan Pendapatan Daerah-Bank Kasda; 4) Pelaksanaan Pendapatan Daerah-Bank lain; 5) Penatausahaan Penerimaan, 6) Penatausahaan Penerimaan dengan Bendahara Pembantu.

Akuntansi dan Pelaporan, didalamnya menyusun laporan berkaitan: 1) Akuntansi SKPD; 2) Laporan Keuangan SKPD; 3) Akuntansi SKPD; 4) Laporan Keuangan PEMDA; 5) Pertanggungjawaban Pelaksanaan APBD; 6) Pembahasan Laporan Keuangan PEMDA.

Perubahan APBD, didalamnya menyusun laporan tentang: 1) Penyusunan KUA dan PPAS Perubahan APBD; 2) Penyiapan Pedoman Penyusunan RKA SKPD untuk Perubahan APBD; 3) Penyusunan RKA SKPD Perubahan APBD; 4) Pnyiapan Raperda Perubahan APBD; 5) Pembahasan Raperda PerubahanAPBD; 6) Evaluasi Raperda Perubahan APBD dan Raper KDH Penjabaran P-APBD; 7) Penetapan Perda Perubahan APBD dan Per KDHPenjabaran P-APBD, 8) Pembatalan Perda Perubahan APBD dan Per KDH-Penjabaran P-APBD; 8) Penyusunan Rancangan DPPA SKPD; 9) Pembahasan Rancangan DPPA SKPD, 10) Pengesahan Rancangan DPPA SKPD.

Kebijakan tersebut merupakan landasan bagi penyelenggaraan kegiatan akuntansi mulai dari satuan kerja pengguna anggaran, penyusunan laporan keuangan oleh Entitas Pelaporan dan penyajiannya kepada BPK untuk diaudit, hingga penyampaian Rancangan Peraturan Daerah tentang Pertanggungjawaban Pelaksanaan APBD.

Penyusunan Anggaran Belanja Daerah bertujuan untuk meningkatkan pertumbuhan ekonomi daerah yang disesuaikan dengan siklus anggaran dan merupakan suatu kegiatan menyeluruh, utuh dan terpadu baik 
melalui pendekatan top down approach. Penyusunan anggaran dengan pendekatan top down approach dilakukan langsung oleh departemen dan lembaga non departemen dari pemerintah atasan/pusat. Bottom up approach merupakan proses penyusunan anggaran yang dimulai pemerintahan daerah sampai kepada pemerintahan pusat. Pendekatan ini mengutamakan aspirasi pembangunan dari masyarakat dalam menyusun usulan kegiatan daerah dan usulan proyek daerah. Proses penyusunan anggaran belanja daerah menurut pendekatan bottom up approach dimulai dari mengidentifikasi dan menginventarisasi kebutuhan masyarakat yang disalurkan dari pemerintahan desa/kelurahan melalui musyawarah pembangunan desa (Musrengbangdes) dan diteruskan ke tingkat kecamatan melalui temu karya pembangunan. Rakorbang II ditingkat kabupaten/kota, Rakorbang I ditingkat provinsi dan akhirnya Rakornas ditingkat nasional.

Usulan rencana anggaran belanja pembangunan pada tingkat desa/kelurahan akan dibahas melalui musyawarah pembangunan desa. Hasil pembahasannya diusulkan kepada pemerintahan kecamatan yang akan dibahas dalam temu karya pembangunan. Hasil temu karya pembangunan akan diusulkan kepada pemerintah kabupaten/kota dalam rapat koordinasi pembangunan (rakorbang) ditingkat kabupaten/ kota. Pada rakorbang ditingkat kabupaten/ kota ini akan muncul proyek-proyek yang akan dibiayai dari pendapatan asli daerah dan pemerintah atasan. Usulan rencana anggaran belanja pembangunan yang akan dibiayai oleh pemerintah pusat akan dibahas dalam rapat koordinasi regional tingkat provinsi dan tingkat nasional. Anggaran belanja pembangunan dalam bentuk proyek yang telah disetujui oleh pemerintah pusat serta proyek-proyek yang diprioritaskan pembiayaannya dari pendapatan asli daerah akan dijadikan bahan, pedoman dan acuan dalam penyusunan Anggaran Pendapatan dan Belanja Daerah (APBD).

Proses penyusunan Anggaran Pendapatan dan Belanja Daerah (APBD) Pemerintah Provinsi Kalimantan Timur disusun berdasarkan tahap-tahap sebagai berikut: Pertama, Penyusunan Rencana Kerja Dan Anggaran (RKA) SKPD adalah Seluruh penerimaan dan pengeluaran pemerintahan daerah baik dalam bentuk uang, barang dan/atau jasa pada tahun anggaran yang berkenaan harus dianggarkan dalamAPBD. Penganggaran penerimaan dan pengeluaran APBD harus memiliki dasar hukum penganggaran. Anggaran belanja daerah diprioritaskan untuk melaksanakan kewajiban pemerintahan daerah sebagaimana ditetapkan dalam peraturan perundang-undangan.

Untuk menyusun APBD, Pemerintah daerah menyusun RKPD yang merupakan penjabaran dari RPJMD dengan menggunakan bahan dari Renja SKPD untuk jangka waktu 1 (satu) tahun yang mengacu kepada Rencana Kerja Pemerintah. RKPD memuat rancangan kerangka ekonomi daerah, prioritas pembangunan dan kewajiban daerah, rencana kerja yang terukur dan pendanaannya, baik yang dilaksanakan langsung oleh pemerintah, pemerintah daerah maupun ditempuh dengan mendorong partisipasi masyarakat. Kewajiban daerah mempertimbangkan prestasi capaian standar pelayanan minimal yang ditetapkan sesuai dengan peraturan perundangundangan.

RKPD disusun untuk menjamin keterkaitan dan konsistensi antara perencanaan, penganggaran, pelaksanaan, dan pengawasan. Penyusunan RKPD diselesaikan paling lambat akhir bulan Mei 
sebelum tahun anggaran berkenaan. RKPD ditetapkan dengan peraturan kepala daerah. Tata cara penyusunan RKPD berpedoman pada peraturan perundang-undangan.

Kepala daerah menyusun rancangan KUA berdasarkan RKPD dan pedoman penyusunan APBD yang ditetapkan Menteri Dalam Negeri setiap tahun. Pedoman penyusunan APBD memuat antara lain: a.pokok-pokok kebijakan yang memuat sinkronisasi kebijakan pemerintah dengan pemerintah daerah; b.prinsip dan kebijakan penyusunan APBD tahun angaran berkenaan.

Rancangan KUA memuat target pencapaian kinerja yang terukur dari program-progam yang akan dilaksanakan oleh pemerintahan daerah untuk setiap urusan pemerintah daerah yang disertai dengan proyeksi pendapatan daerah, alokasi belanja daerah, sumber dan penggunaan pembiayaan teknis penyusunan APBD. yang disertai dengan asumsi yang mendasarinya. Program-program tersebut diselaraskan dengan prioritas pembangunan yang ditetapkan oleh pemerintah. Asumsi yang mendasari yakni mempertimbangkan perkembangan ekonomi makro dan perubahan pokok-pokok kebijakan fiskal yang ditetapkan oleh pemerintah.

Dalam menyusun rancangan KUA Kepala daerah dibantu oleh TAPD yang dipimpim oleh Sekretaris daerah. Rancangan KUA yang telah disusun, disampaikan oleh sekretaris daerah selaku koordinator pengelola keuangan daerah kepada kepala daerah, paling lambat pada awal bulan Juni.

Rancangan KUA disampaikan kepala daerah kepada DPRD paling lambat pertengahan bulan Juni tahun anggaran berjalan untuk dibahas dalam pembicaraan pendahuluan RAPBD tahun anggaran berikutnya. Pembahasan dilakukan oleh
TAPD bersama penitia anggaran DPRD. Rancangan KUA yang telah dibahas selanjutnya disepakati menjadi KUA paling lambat minggu pertama bulan juli tahun anggran berjalan.

Berdasarkan KUA yang telah disepakati, pemerintah daerah menyusun rancangan PPAS. Rancangan PPAS disusun dengan tahapan sebagai berikut: a. menentukan skala prioritas untuk urusan wajib dan urusan pilihan; b. menentukan urutan program untuk masing-masing urusan; dan c. menyusun plafon anggaran sementara untuk masing-masing program.

Kepala daerah menyampaikan rancangan PPAS yang telah disusun kepada DPRD untuk dibahas paling lambat minggu kedua bulan Juli tahun anggaran berjalan. Pembahasan dilakukan oleh TAPD bersama panitia anggaran DPRD.

Rancangan PPAS yang telah dibahas selanjutnya disepakati menjadi PPA paling lambat akhir bulan Juli tahun anggaran berjalan. KUA serta PPA yang telah disepakati, masing-masing dituangkan ke dalam nota kesepakatan yang ditandatangani bersama antara kepala daerah dengan pimpinan DPRD. Dalam hal kepala daerah berhalangan, yang bersangkutan dapat menunjuk pejabat yang diberi wewenang untuk menandatangani nota kesepakatan KUA dan PPA. Dalam hal kepala daerah berhalangan tetap, penandatanganan nota kesepakatan KUA dan PPA dilakukan oleh pejabat yang ditunjuk oleh pejabat yang berwenang.

Berdasarkan nota kesepakatan, TAPD menyiapkan rancangan keputusan suarat edaran kepala daerah tentang pedoman penyusunan RKA-SKPD sebagai acuan kepala SKPD dalam menyusun RKA-SKPD. Rancangan surat edaran kepala daerah tentang pedoman penyusunan 
RKA-SKPD mencakup: a. PPA yang dialokasikan untuk setiap program SKPD berikut rencana pendapatan dan pembiayaan; b. sinkronisasi program dan kegiatan antar SKPD terkait dengan kinerja SKPD berkenaan sesuai dengan standar pelayanan minimal yang ditetapkan; c.batas waktu penyampaian RKA-SKPD kepada PPKD; d. hal-hal lainnya yang perlu mendapatkan perhatian dari SKPD terkait dengan prinsip-prinsip peningkatan efisiensi, efektifitas, tranparansi dan akuntabilitas penyusunan anggaran dalam rangka pencapaian prestasi kerja; dan e. dokumen sebagai lampiran meliputi KUA, PPA, kode rekening APBD, format RKA-SKPD, analisis belanja dan standar satuan harga.

Surat edaran kepala daerah perihal pedoman penyusunan RKA-SKPD diterbitkan paling lambat awal bulan Agustus tahun anggaran berjalan.

Berdasarkan pedoman penyusunan RKA-SKPD, Kepala SKPD menyusun RKA-SKPD. RKA-SKPD disusun dengan menggunakan pendekatan kerangka pengeluaran jangka menengah daerah, penganggaran terpadu dan penganggaran berdasarkan prestasi kerja.

Pendekatan kerangka pengeluaran jangka menengah dilaksanakan dengan menyusun prakiraan maju. Prakiraan maju berisi perkiraan kebutuhan anggaran untuk program dan kegiatan yang direncanakan dalam tahun anggaran berikutnya dari tahun anggaran yang direncanakan. Pendekatan penganggaran terpadu dilakukan dengan memadukan seluruh proses perencanaan dan penganggaran pendapatan, belanja dan pembiayaan di lingkungan SKPD untuk menghasilkan dokumen rencana kerja dan anggaran.

Pendekatan penganggaran berdasarkan prestasi kerja dilakukan dengan mem- perhatikan keterkaitan antara pendanaan dengan keluaran yang diharapkan dari kegiatan dan hasil serta manfaat yang diharapkan termasuk efisiensi dalam pencapaian hasil dan keluaran tersebut.

Untuk terlaksananya penyusunan RKA-SKPD berdasarkan pendekatan dan terciptanya kesinambungan RKA-SKPD, kepala SKPD mengevaluasi hasil pelaksanaan program dan kegiatan 2 (dua) tahun anggaran sebelumnya sampai dengan semester pertama tahun anggaran berjalan. Evaluasi bertujuan menilai program dan kegiatan yang belum dapat dilaksanakan dan/ atau belum diselesaikan tahun-tahun sebelumnya untuk dilaksanakan dan/atau diselesaikan pada tahun yang direncanakan atau 1 (satu) tahun berikutnya dari tahun yang direncanakan. Dalamhal suatu program dan kegiatan merupakan tahun terakhir untuk pencapaian prestasi kerja yang ditetapkan, kebutuhan dananya harus dianggarkan pada tahun yang direncanakan.

Penyusunan RKA-SKPD berdasarkan prestasi kerja berdasarkan pada indikator kinerja, capaian atau target kinerja, analisis standar belanja, standar satuan harga, dan standar pelayanan minimal. Indikator kinerja adalah ukuran keberhasilan yang akan dicapai dari program dan kegiatan yang direncanakan. Capaian kinerja merupakan ukuran prestasi kerja yang akan dicapai yang berwujud kualitas, kuantitas, efisiensi dan efektifitas pelaksanaan dari setiap program dan kegiatan. Analisis standar belanja merupakan penilaian kewajaran atas beban kerja dan biaya yang digunakan untuk melaksanakan suatu kegiatan. Standar satuan harga merupakan harga satuan setiap unit barang/jasa yang berlaku disuatu daerah yang ditetapkan dengan keputusan kepala daerah. Standar pelayanan minimal merupakan tolok ukur kinerja dalam menentukan 
capaian jenis dan mutu pelayanan dasar yang merupakan urusan wajib daerah.

RKA-SKPD sebagaimana dimaksud dalam memuat rencana pendapatan, rencana belanja untuk masing-masing program dan kegiatan, serta rencana pembiayaan untuk tahun yang direncanakan dirinci sampai dengan rincian objek pendapatan, belanja dan pembiayaan serta prakiraan maju untuk tahun berikutnya. RKA-SKPD juga memuat informasi tentang urusan pemerintah daerah, organisasi, standar biaya, presentasi kerja yang akan dicapai dari program dan kegiatan.

Rencana pendapatan memuat kelompok, jenis, obyek dan rincian obyek pendapatan daerah, yang dipungut/dikelola/ diterima oleh SKPD sesuai dengan tugas pokok dan fungsinya, ditetapkan berdasarkan peraturan perundang-udangan. Peraturan perundang-undangan adalah peraturan daerah, peraturan pemerintah atau undang-undang. Rencana belanja memuat kelompok belanja tidak langsung dan belanja langsung yang masing-masing diuraikan menurut jenis, obyek dan rincian obyek belanja. Rencana pembiayaan memuat kelompok penerimaan pembiayaan yang dapat digunakan untuk menutup defisit APBD dan pengeluaran pembiayaan yang digunakan untuk memanfaatkan surplus APBD yang masing-masing diuraikan menurut jenis, obyek dan rincian obyek pembiayaan.

Urusan pemerintahan daerah memuat bidang urusan pemerintahan daerah yang dikelola sesuai dengan tugas pokok dan fungsi organisasi. Organisasi memuat nama organisasi atau nama SKPD selaku pengguna anggaran/pengguna barang. Prestasi kerja yang hendak dicapai terdiri dari indikator, tolok ukur kinerja dan target kinerja.
Program memuat nama program yang akan dilaksanakan SKPD dalam tahun anggaran berkenaan.

Kegiatan memuat nama kegiatan yang akan dilaksanakan SKPD dalam tahun anggaran berkenaan. Indikator meliputi masukan, keluaran dan hasil. Tolok ukur kinerja merupakan ukuran prestasi kerja yang akan dicapai dari keadaan semula dengan mempertimbangkan faktor kualitas, kuantitas, efisiensi dan efektifitas pelaksanaan dari setiap program dan kegiatan. Target kinerja merupakan hasil yang diharapkan dari suatu program atau keluaran yang diharapkan dari suatu kegiatan.

Belanja langsung yang terdiri dari belanja pegawai, belanja barang dan jasa, serta belanja modal dianggarkan dalam RKA-SKPD pada masing-masing SKPD. Belanja bunga, belanja subsidi, belanja hibah, belanja bantuan sosial, belanja bagi hasil, belanja bantuan keuangan, dan belanja tidak terduga hanya dianggarkan dalam RKA-SKPD pada SKPKD. Penerimaan pembiayaan dan pengeluaran pembiayaan daerah dianggarkan dalam RKA-SKPD pada SKPKD.

RKA-SKPD yang telah disusun oleh SKPD disampaikan kepada PPKD untuk dibahas lebih lanjut oleh TAPD. Pembahasan oleh TAPD dilakukan untuk menelaah kesesuaian antara RKA-SKPD dengan KUA, PPA, prakiraan maju yang telah disetujui tahun anggaran sebelumnya, dan dokumen perencanaan lainnya, serta capaian kinerja, indikator kinerja, standar analisis belanja, standar satuan harga, standar pelayanan minimal, serta sinkronisasi program dan kegiatan antar SKPD. Dalam 
hal hasil pembahasan RKA-SKPD terdapat ketidaksesuaian maka SKPD melakukan penyempurnaan.

RKA-SKPD yang telah disempurnakan oleh SKPD disampaikan kepada PPKD sebagai bahan penyusunan rancangan peraturan daerah tentang APBD dan rancangan peraturan kepala daerah tentang penjabaran APBD. Rancangan peraturan daerah tentang APBD dilengkapi dengan lampiran yang terdiri dari: a. ringkasan APBD; b. ringkasan APBD menurut urusan pemerintahan daerah dan organisasi; $c$. rincian $A P B D$ menurut urusan pemerintahan daerah, organisasi, pendapatan, belanja dan pembiayaan; d. rekapitulasi belanja menurut urusan pemerintahan daerah, organisasi, program dan kegiatan; e. rekapitulasi belanja daerah untuk keselarasan dan keterpaduan urusan pemerintahan daerah dan fungsi dalam kerangka pengelolaan keuangan negara; $f$. daftar jumlah pegawai per golongan dan per jabatan; g. daftar piutang daerah; $h$. daftar penyertaan modal (investasi) daerah; i.daftar perkiraan penambahan dan pengurangan aset tetap daerah; j. daftar perkiraan penambahan dan pengurangan aset lain-lain; k. Daftar kegiatan-kegiatan tahun anggaran sebelumnya yang belum diselesaikan dan dianggarkan kembali dalam tahun anggaran ini; 1 . daftar dana cadangan daerah; dan $\mathrm{m}$. daftar pinjaman daerah.

Kepala daerah menyampaikan rancangan peraturan daerah tentang APBD beserta lampirannya kepada DPRD paling lambat pada minggu pertama bulan Oktober tahun anggaran sebelumnya dari tahun yang direncanakan untuk mendapatkan persetujuan bersama. Pengambilan keputusan bersama DPRD dan kepala daerah terhadap rancangan peraturan daerah ten- tang APBD dilakukan paling lama 1 (satu) bulan sebelum tahun anggaran yang bersangkutan dilaksanakan. Atas dasar persetujuan bersama, kepala daerah menyiapkan rancangan peraturan kepala daerah tentang penjabaran APBD. Penyampaian rancangan peraturan daerah disertai dengan nota keuangan. Dalam hal kepala daerah dan/atau pimpinan DPRD berhalangan tetap, maka pejabat yang ditunjuk dan ditetapkan oleh pejabat yang berwenang selaku pejabat/pelaksana tugas kepala daerah dan/ atau selaku pimpinan sementara DPRD yang menandatanganu persetujuan bersama.

Apabila DPRD sampai batas waktu tidak menetapkan persetujuan bersama dengan kepala daerah terhadap rancangan peraturan daerah tentang APBD, kepala daerah melaksanakan pengeluaran setinggitingginya sebesar angka APBD tahun anggaran sebelumnya untuk membiayai keperluan setiap bulan. Pengeluaran setinggi-tingginya untuk keperluan setiap bulan diprioritaskan untuk belanja yang bersifat mengikat dan belanja yang bersifat wajib. Belanja yang bersifat mengikat merupakan belanja yang dibutuhkan secara terus menerus dan harus dialokasikan oleh pemerintah daerah dengan jumlah yang cukup untuk keperluan setiap bulan dalam tahun anggaran yang bersangkutan, seperti belanja pegawai, belanja barang dan jasa. Belanja yang bersifat wajib adalah belanja untuk terjaminnya kelangsungan pemenuhan pendanaan pelayanan dasar masyarakat antara lain pendidikan dan kesehatan dan/atau melaksanakan kewajiban kepada fihak ketiga.

Rencana pengeluaran disusun dalam rancangan peraturan kepala daerah tentang APBD. Rancangan peraturan kepala daerah dapat dilaksanakan setelah memper- 
oleh pengesahan dari gubernur bagi kabupaten/kota. Pengesahan rancangan peraturan kepala daerah tentang APBD ditetapkan dengan keputusan keputusan gubernur bagi kabupaten/kota.

Kedua, Pelaksanaan APBD dan Dokumen Pelaksanaan Anggaran (DPA) yaitu Pejabat Pengelolan Keuangan Daerah (PPKD) paling lama 3 (tiga) hari kerja setelah peraturan daerah tentang APBD ditetapkan, memberitahukan kepada semua kepala SKPD agar menyusun rancangan DPA-SKPD. Rancangan DPA-SKPD, merinci sasaran yang hendak dicapai, program, kegiatan, anggaran yang disediakan untuk mencapai sasaran tersebut, dan rencana penarikan dana tiap-tiap SKPD serta pendapatan yang diperkirakan.

Kepala SKPD menyerahkan rancangan DPA-SKPD kepada PPKD paling lambat 6 (enam) harikerja setelah pemberitahuan. Format DPA-SKPD tercantum dalam B.I.a dan Lampiran B.I.bPermendagri No. 59 Tahun 2007.

Tim anggaran pemerintah daerah melakukan verifikasi rancangan DPA-SKPD bersama-sama dengan kepala SKPD paling lambat 15 (lima belas) hari kerja sejak ditetapkannya peraturan kepala daerah tentang penjabaran APBD.

Berdasarkan hasil verifikasi, PPKD mengesahkan rancangan DPA-SKPD dengan persetujuan sekretaris daerah. DPA-SKPD yang telah disahkan disampaikan kepada kepala SKPD, satuan kerja pengawasan daerah, dan Badan Pemeriksa Keuangan lama 7 (tujuh) hari kerja sejak tanggal disahkan. DPA-SKPD digunakan sebagai dasar pelaksanaan anggaran oleh kepala SKPD selaku pengguna anggaran/ barang.

Dalam menilai pelaksanaan APBD Pemerintah Provinsi Kalimantan Timur selain
DataAPBD, PAD dan belanja rutin/belanja tidak langsung Pemerintah Provinsi Kalimantan Timur juga dapat mempertimbangkan pemberian opini BPK mengenai tingkat kewajaran informasi yang disajikan dalam laporan keuangan yang didasarkan pada: Keseuaian dengan standar akuntansi pemerintahan, Kecukupan pengungkapan, Kepatuhan terhadap peraturan perundangundangan, dan Efektivitas sistem pengendalian intern

Dengan memperhatikan pemberian opini tersebut, pada dasarnya terdapat dua kondisi menentukan opini yaitu: Pembatasan lingkup audit atau kecukupan bukti, Penyimpangan dari prinsip akuntansi atau salah saji.

Hal- hal yang perlu dicermati untuk disiapkan untuk meraih opini WTP adalah sebagai berikut: Sistem Pembukuan, di dalamnya menyusunan pertanggung jawaban keuangan negara berupa laporan keuangan yang mengacu pada SAP Tahun 2005. Laporan Keuangan terdiri dari Neraca, Laporan Realisasi Anggaran, Laporan Arus Kas, dan Catatan Atas Laporan Keuangan, yang dilampiri dengan laporan keuangan BUMD dan badan lainnya. kemudian menggunakan Sistem Perbendaharaan Tunggal (Single Treasury Account), selain Rekening Dana Dana Alokasi Khusus Pemda.

Sistem Aplikasi Teknologi Komputer yaitu meliputi: Sistem Aplikasi Teknologi Komputer yang terintegrasi, Meliputi aspek Pendapatan, Belanja dan Pembiayaan tiap tahunnya, Sistem mampu menghasilkan Lapkeuangan yang handal, akurat dan akuntable, Ada baiknya terintegrasi dengan Aplikasi Sistem Informasi Manajemen Barang Daerah (SIMBADA) 
Inventarisasi Aset adalah Aset Daerah yang perlu diinventarisasi sesuai peraturan perundang-undangan dan disertai dengan bukti kepemilikan yang sah dan dicatat serta dipertanggungjawabkan dalam neraca

Jadwal waktu penyusunan laporan keuangan dan pemeriksaan serta pertanggung jawaban anggaran. Laporan keuangan disampaikan untuk diperiksa BPK paling lambat 3 bulan setelah tahun anggaran berakhir.

Quality Assurance yang dilakukan oleh Pengawas Intern yaitu Pengawas Internal (Irjen, SPI dan Inspektorat/Bawasda
Provinsi serta Kabupaten/Kota) bertugas untuk mengawasimutu laporan pertanggung jawaban keuangan yang disusun oleh Pemerintah Daerah.

Sumber Daya Manusia, yaitu Penetapan status bendahara sebagai jabatan fungsional, pemilihan bendahara atau pegawai yang menangani pembukuan dan pengawasan seyogyanya memiliki pengetahuan dasar ilmu akuntansi, serta SDM dapat diperoleh dengan merekrut tenaga BPKP atau dengan memberikan pelatihan kepada pegawai mengenai akuntansi keuangan daerah.

Tabel 1. Opini BPK atas LKPD tahun 2008 sampai dengan tahun 2012 Provinsi Kalimantan Timur

\begin{tabular}{clccccc}
\hline \multirow{2}{*}{ No } & \multirow{2}{*}{ Nama Pemda } & \multicolumn{5}{c}{ Tahun } \\
\cline { 3 - 6 } & & 2008 & 2009 & 2010 & 2011 & 2012 \\
\hline 1 & Provinsi Kalimantan Timur & TW & TW & WDP & WDP & WTP \\
2 & Kab. Berau & TW & TW & WDP & WDP & WTP \\
3 & Kab. Bulungan & TW & TW & WDP & WDP & WDP \\
4 & Kab. Kutai Kartanegara & TW & TW & TW & WDP & WTP \\
5 & Kab. Kutai Barat & TW & TW & WDP & WDP & WDP \\
6 & Kab. Kutai Timur & TMP & TMP & TW & TW & WDP \\
7 & Kab. Malinau & TW & WDP & TW & WDP & WDP \\
8 & Kab. Nunukan & WDP & TW & TW & WDP & WTP \\
9 & Kab. Paser & TW & TW & TW & WDP & WDP \\
10 & Kota Balikpapan & WDP & WDP & WDP & WDP & WDP \\
11 & Kota Bontang & WDP & WDP & WDP & WDP & WDP \\
12 & Kota Samarinda & TMP & TMP & TMP & TMP & WDP \\
13 & Kota Tarakan & WDP & WDP & WDP & WDP & WTP \\
14 & Kab. PPU & WDP & TW & TW & WDP & WDP \\
15 & Kab. Tana Tidung & TMP & TMP & TMP & TMP & - \\
\hline
\end{tabular}

Sumber: Inspektorat Provinsi Kalimantan Timur

\section{Keterangan:}

TMP: Tidak Memberikan Pendapat TW: Tidak Wajar

WDP: Wajar Dengan Pengecualian WTP: Wajar Tanpa Pengecualian 
Pada tabel 1 terlihat bahwa opini BPK atas LKPD pada Pemerintah Provinsi Kalimantan Timur mengalami peningkatan dari tahun 2008 dan 2009 dengan predikat opini Tidak Wajar (TW), selanjutnya pada tahun 2010 dan 2011 dengan predikat Wajar Dengan Pengecualian (WDP) dan akhirnya pada tahun 2012 memperoleh predikat opini Wajar Tanpa Pengecualian (WTP). Selain Pemerintah Provinsi Kalimantan Timur, Kabupaten Berau, Kabupaten Kutai Kartanegara, Kabupaten Nunukan dan Kota Tarakan juga memperoleh predikat opini Wajar Tanpa Pengecualian (WTP). Sementara Kabupaten/ Kota yang lain di Provinsi Kalimantan Timur masih memperoleh predikat opini Wajar Dengan Pengecualian (WDP).

Pemerintah melakukan pembinaan dan pengawasan pengelolaan keuangan daerah kepada pemerintah daerah yang dikoordinasikan oleh menteri dalam negeri, untuk kabupaten/kota dikoordinasikan oleh gubernur selaku wakil pemerintah meliputi pemberian pedoman, bimbingan, supervisi, konsultasi, pendidikan, pelatihan serta penelitian dan pengembangan.

Pemberian pedoman mencakup perencanaan dan penyusunan APBD, penatausahaan, pertanggungjawaban keuangan daerah, pemantauan dan evaluasi, serta kelembagaan pengelolaan keuangan daerah.

Pengawawan pertama dilakukan oleh DPRD, DPRD melakukan pengawasan terhadap pelaksanaan peraturan daerah tentang APBD. DPRD Provinsi dan DPRD Kabupaten/Kota melakukan pengawasan legislatif melalui: Pemandangan umum fraksifraksi dalam rapat paripurna DPRD, rapat pembahasan dalam sidang komisi, rapat pembahasan dalam panitia-panitia yang dibentuk berdasarkan tata tertib DPRD, rapat dengar pendapat dengan Pemerintah Daerah dan pihak-pihak lain yang diperlukan serta melaksnanakan Kunjungan kerja.

Dalam melaksanakan pengawasan legislatif DPRD dapat: 1) Mengundang pejabat-pejabat di lingkungan Pemerintah Daerah untuk dimintai keterangan, pendapat dan saran; 2) menerima, meminta dan mengusahakan untuk memperoleh keterangan dari pejabat/pihak-pihak yang terkait. 3) Meminta kepada pihak-pihak tertentu melakukan penyelidikan dan atau pemeriksaan. 4) Memberi saran mengenai langkahlangkah preventif dan represif kepada pejabat yang berwenang

Pengawasan dana APBD oleh Inspektorat Provinsi Kalimantan Timur dilakukan sesuai dengan peraturan perundangundangan. Untuk meningkatkan efisiensi dan efektivitas dalam pengelolaan keuangan daerah, Kepala Daerah menugaskan Inspektorat Provinsi Kalimantan Timur untuk melakukan pengawasan fungsional mencakup seluruh aspek keuangan daerah termasuk pemeriksaan tata laksana penyelenggaraan program kegiatan dan manajemen pemerintah daerah.

Pengawasan kedua dilakukan oleh Inspektorat Provinsi Kalimantan Timur melalui kegiatan: a) Pemeriksaan berkala, pemeriksaan insidential maupun pemeriksaan terpadu; b) Pengujian terhadap laporan berkala atau sewaktu-waktu dari SKPD; c) Pengusutan atas kebenaran laporan mengenai adanya indikasi terjadinya korupsi, kolusi dan nepotisme; d) Penilaian atas manfaat dan keberhasilan kebijakan, pelaksanaan program dan kegiatan.

Inspektorat Provinsi Kalimantan Timur telah melaksanakan pengawasan terhadap pengelolaan keuangan daerah yang dikelola 
SKPD, termasuk menguji apakah pertanggung jawaban keuangan telah didukung oleh bukti yang memadai. Setiap akhir tahun juga dilaksanakan reviu atas laporan keuangan yang dilaksanakan oleh SKPD.

Ada beberapa kendala dalam pengawasan Inspektorat Provinsi Kalimantan Timur yaitu antara lain: a) Kekurangan tenaga/SDM pemeriksa dibandingkan jumlah SKPD yang dibina dan besaran anggaran yang dikawal; b) Masih tumpang tindihnya pembinaan pengawasan oleh instansi pusat dan kadang-kadang menjadi pertentangan dalam pelaksanaannya, sehingga terjadi keraguan/kebingungan; c) Tidak adanya lembaga/Bidang Litbang untuk merumuskan aturan yang akan dikelola; dan d) Di SKPD kekurangan SDM akuntansi atau mengerti pengelolaan keuangan daerah.

Pengawasan ketiga dilakukan oleh masyarakat, dimana masyarakat melakukan pengawasan atas penyelenggaraan Pemerintahan Daerah meliputi: a) Pemberian informasi adanya indikasi terjadinya korupsi, kolusi dan nepotisme dilingkungan Pemerintah Daerah maupun DPRD; b) Penyampaian pendapat dan saran mengenai perbaikan, penyempurnaan baik preventif maupun represif atas masalah yang disampaikan.

Pengawasan masyarakat disampaikan kepada pejabat yang berwenang dan atau instansi yang terkait. Disamping itu, masyarakat berhak memperoleh informasi perkembangan penyelesaian masalah yang diadukan kepada pejabat yang berwenang.

Pengawasan keempat dilaksanakan oleh BPK, diamana prosedur pelaksanaan dengan cara meminta dokumen yang wajib disampaikan oleh pejabat atau pihak lain yang berkaitan dengan pelaksanaan pemeriksaan pengelolaan dan tanggung jawab keuangan daerah. Mengakses semua data yang disimpan di berbagai media, aset, lokasi dan segala jenis barang atau dokumen dalam penguasaan atau kendali dari entitas yang menjadi objek pemeriksaan atau entitas lain yang dipandang perlu dalam pelaksanaan tugas pemeriksaannya.

Melakukan penyegelan tempat menyimpan uang, barang dan dokumen pengelolaan keuangan daerah. Meminta keterangan kepada seseorang, dilakukan oleh pemeriksa untuk memperoleh, melengkapi dan/atau unsur pidana. Apabila dalam pemeriksaan ditemukan unsur pidana, BPK segera melaporkan hal tersebut kepada instansi yang berwenang sesuai dengan ketentuan perundang-undangan.

Dari hasil penelitian yang telah dilakukan ketika melakukan wawancara kepada informan bahwa proses perencanaan yang dilakukan di Pemerintah Provinsi Kalimantan Timur tidak terlepas dari hambatan dan permasalahan dilapangan, dimana berbagai kepentingan yang terkadang saling bertolak belakang antara pihak eksekutif dan legislatif, sehingga dapat berdampak pada lambannya proses penetapan kebijakan keuangan daerah yang selanjutnya akan mempengaruhi kegiatan pembangunan dan pelayanan di daerah ini.

Berkaitan dengan proses penyusunan anggaran, pelaksanaan dan pertanggung jawaban kebijakan pengelolaan keuangan daerah ditanggapi oleh Kepala Bagian Anggaran Biro Keuangan Setda Provinsi Kalimantan Timur: "Proses penyusunan anggaran, Pelaksanaan, Pengawasan dan pertanggung Jawaban Kebijakan Pengelolaan Keuangan Daerah Provinsi Kalimantan Timur berdasarkan Perspektif Permendagri No. 13 Tahun 2006 sudah memadai sebagai landasan/dasar/acuan dalam proses pengganggaran, penatausahaan, pengawasan dan pelaporan." 
Dalam implementasi dan penerapan kebijakan pengelolaan daerah telah diatur tentang petunjuk teknis mengenai penatausahaan, pengawasan dan pelaporan keuangan. Namun, dari proses penyusunan, pelaksanaan dan pengawasan anggaran belanja daerah pemerintah Provinsi Kalimantan Timur terdapat beberapa kelemahan antara lain: 1. Pemahaman entitas terhadap regulasi, sistem yang diterapakan masih kurang; 2. Regulasi pengelolaan keuangan tidak sinkron dan antara APBD dengan pengelolaan APBN; 3.Kekurangan tenaga/ SDM pemeriksa dibandingkan jumlah SKPD yang dibina dan besaran anggaran yang dikawal; 4. Masih tumpang tindihnya pembinaan pengawasan oleh Instansi Pusat dan kadang-kadang menjadi pertentangan dalam pelaksanaannya sehingga terjadi keraguan/kebingungan; 5.Tidak adanya lembaga/Bidang Litbang untuk merumuskan aturan yang akan dikelola; 6. Di SKPD kekurangan SDM akuntansi atau mengerti pengelolaan keuangan daerah.

Dalam pengelolaan keuangan Daerah diatur petunjuk teknis mengenai Penatausahaan Keuangan Dan Penyusunan Laporan Keuangan, namun hal yang menjadi permasalahan klasik dimana peraturan pengelolaan keuangan daerah terus mengalami perubahan, terakhir dengan dikeluarkannya Permendagri No. 13 Tahun 2006 sehingga dibutuhkan pemahaman mendasar dan teknis dari seluruh pejabat Pemerintah Provinsi Kalimantan Timur (para SKPD) dengan sistem pengelolaan keuangan daerah yang baru.

\section{Penutup}

Berdasarkan hasil penelitian dan analisis data, maka dapat ditarik beberapa kesimpulan tentang Pengelolaan Keuangan
Pemerintah Daerah Perspektif Permendagri No. 13 Tahun 2006 Pada Pemerintah Provinsi Kalimantan Timur sebagai berikut: 1. Proses Penyusunan Anggaran Pendapatan dan Belanja Daerah (APBD) di Provinsi Kalimantan Timur sesuai fakta telah sesuai dengan aspirasi masyarakat daerah. Hal ini sesuai dengan pelaksanaan kegiatan program pada suatu SKPD berdasarkan data dari masyarakat; 2. Pelaksanaan Keuangan Daerah berdasarkan Permendagri No. 13 Tahun 2006 dicatat dalam sistem pengelolaan keuangan daerah Simda Keuangan dan Simda barang untuk keuangan daerah ditambah lagi sistem Penerimaan PAD. Output Simda Keuangan adalah Laporan Keuanga SKPD/Provinsi semester 1 dan akhir; 3. Pengelolaan kegiatan program pada JajaranSKPD Provinsi Kaltim pada umumnya telah efektif dan efisien. Efektifitas dan efisiensi ini didukung oleh Aparat Pengawasan Internal, Inspektorat Provinsi Kaltim dan BPK RI. Hal ini terbukti dengan hasil pemeriksaan dari Inspektorat Provinsi Kaltim dan Opini BPK RI.

\section{DAFTAR PUSTAKA}

Undang-Undang Republik Indonesia Nomor 17 Tahun 2003 Tentang Keuangan Negara

Peraturan Menteri Dalam Negeri Republik Indonesia Nomor 13 Tahun 2006 Tentang Pedoman Pengelolaan Keuangan Daerah

Peraturan Pemerintah Republik Indonesia Nomor 58 Tahun 2005 Tentang Pengelolaan Keuangan Daerah,

Peraturan Pemerintah Nomor 71 Tahun 2007 tentang Standar Akuntansi Pemerintah (SAP). 
Studi tentang Pengelolaan Keuangan Daerah Perspektif Permendagri... (Al Mukaddas)

Fitrie, Syafrida. 2008. Pengelolaan Keuangan Daerah Perspektif Permendagri No. 13 Tahun 2006 pada Pemerintah Kota Binjai. Tesis. Universitas Sumatera Utara Medan.

Moleong, Lexy. 2000. Metodologi Penelitian Kualitatif. Remaja Rosdakarya. Bandung. 
